\title{
Effects of irrigation with treated agro-industrial wastewater on soil chemical characteristics and fungal populations during processing tomato crop cycle
}

\author{
G. Disciglio*, G. Gatta, A. Libutti, A. Gagliardi, A. Carlucci, F. Lops, F. Cibelli, A. \\ Tarantino
}

Department of Science of Agriculture, Food and the Environment, University of Foggia, Via Napoli, 25, 70122

Foggia, Italy. *Corresponding author: grazia.disciglio@unifg.it

\begin{abstract}
This study was carried out in 2012 at Stornarella (Italy; 41 ${ }^{\circ} 15^{\prime} 29^{\prime \prime} \mathrm{N} ; 15^{\circ} 43^{\prime} 56^{\prime \prime} \mathrm{E} ; 154 \mathrm{~m}$ a.s.l.). We investigated the effects of reuse of secondary treated agro-industrial wastewater for irrigation, in comparison with conventional groundwater, and we monitored soil chemical characteristics and fungal populations during the crop cycle of processing tomato (Solanum lycopersicum L.). Compared to the groundwater, the wastewater had significantly higher electrical conductivity, total suspended solids, sodium, calcium, magnesium, potassium, sodium adsorption ratio, chemical oxygen demand, biological oxygen demand over five days, ammoniumnitrogen, phenols, bicarbonates, phosphates, sulphates and chlorides. Most of these parameters were significantly greater also in the wastewater-irrigated soil. During the tomato crop cycle, there were significant shifts in the structure of the soil microfungal community. Saprophytic species increased in the wastewater-treated soil, while phytopathogens such as Fusarium oxysporum progressively decreased. More investigations into the mechanisms by which wastewater acts on disease suppression is needed to make the use of such wastewaters more predictable. The irrigation water source did not significantly affect the qualitative traits of the crop yield. For both irrigation treatments, the most important qualitative parameters that characterized the processing tomato fruit (i.e., dry matter content, $\mathrm{pH}$, soluble solid content, colour parameters) were in agreement with reports in the literature.
\end{abstract}

Keywords: Agro-industrial wastewater, secondary treatment, soil chemical characteristics, soil-borne fungi, processing tomato

\section{Introduction}

Interest in wastewater reuse is constantly developing, and in Europe, Article 13 of Directive 91/271/EEC stipulates that, "The treated wastewater must be reused whenever this is appropriate". This results from the growing demand for non-conventional water resources for irrigation that currently involves all European countries at various levels. Indeed, the importance of treated 
wastewater reuse for irrigation justifies the large number of studies carried out to analyse this issue, especially in arid regions like the several water-short areas of southern Italy (Lopez et al., 2006).

In the Apulia Region (south-eastern Italy), there are numerous agro-industries where the activities are related to the processing of vegetable products, and these release large quantities of wastewater. The costs of disposal of this wastewater can be reduced and the environmental impact minimised through its reuse in agriculture. This is a practice that is considered to be innovative, and also an advantageous alternative towards better use of water resources. Furthermore, in these areas, intensive agricultural systems are widespread, such as for horticulture, and crop rotation is not easy to implement because in some cases it requires heavy changes for technical and economic reasons.

With time, the use of intensive agricultural systems can lead to the development of soil-borne plant pathogens. A practice that is relatively widespread in the horticultural sector is disinfection of the soil with steam or with fumigants. While this generally provides effective results, this method has some disadvantages, among which there is the total loss of biodiversity of soil microorganisms, including those that can fight off pathogens naturally (Garibaldi and Gullino, 1994). In addition, the ban on the use of the most effective fumigant used worldwide for soil disinfestations, methyl bromide, has further increased the need for alternative control methods and numerous plant protection measures for cultivated species.

The use of wastewater can have effects on the chemical and microbiological characteristics of the soil (Meli et al., 2002). The inorganic nutrients present in recycled water can make it potentially useable as a fertiliser source. Also, the chemical characteristics of recycled water, such as $\mathrm{pH}$, salinity, total suspended solids (TSS) and phenolic content, can have direct repressive activities against pathogenic microorganisms, or can indirectly affect the structure of the soil microbial community (Marsilio et al., 2001). Furthermore, when the high content of organic matter in wastewater (compared with that of fresh water) decomposes in the soil, this can increase the population of saprophytic fungi, some of which can act as antagonists of soil-borne plant pathogens, such as Tricoderma spp., Penicillium spp. and Aspergillus spp. (Manici et al., 2004). In this sense, the use of treated agro-industrial wastewater can provide a great contribution to agriculture as well as to environmental recovery.

On the other hand, the use of wastewater in agriculture is often associated with significant health risk, because of high concentrations of human pathogens that are enteric in origin, such as bacteria, viruses, protozoa and helminths. Many studies have analysed this issue to attempt to dispel the doubts about the use of alternative water resources in agriculture, and to provide the legislator with useful scientific knowledge about wastewater reuse (Rubino et al., 2008; Vivaldi et al. 2013).

In this regard, the microbial characteristics of secondary treated wastewater used in the experimental trial reported here have been discussed elsewhere, which included Escherichia coli, Enterococci and Salmonella (Gatta et al., 2015). We reported that in treated agro-industrial effluent, from reduced fraction from domestic wastewater, the microbiological analysis showed low levels of these microorganisms, and the soils and plants irrigated with this wastewater were not contaminated with any bacterial indicators that are generally associated with human health risks. The present study was carried out with the collaboration of agronomists and plant pathologists, and it was aimed at an evaluation of the effects of irrigation with secondary treated agro-industrial wastewater on the chemical and microbial characteristics in comparison 
with conventional groundwater, including the fungal populations of the soil during the processing tomato crop cycle.

\section{Materials and Methods}

\subsection{Site description and experimental layout}

The study was carried out in open field during spring to summer of 2012, at Stornarella (Apulia Region, southern Italy), which is an agricultural area that is characterised by numerous agro-industries that are specialised in processing of vegetable products.

In the experimental field, the effects of two types of irrigation water on the soil chemical characteristics and fungal populations during the processing tomato crop cycle were compared: conventional groundwater and secondary-treated agro-industrial wastewater. The groundwater was pumped from a phreatic well that is normally used by local farmers for crop irrigation, and which was located near the experimental field. The wastewater used originated from the treatment plant of the Fiordelisi company, an agro-industrial firm that is well known for its industrial processing plant for vegetables (dried tomatoes, eggplants, courgettes and peppers, preserved in oil). This treatment plant releases a wastewater volume of $46,500 \mathrm{~m}^{3}$ year-1, with an average flow rate of $15 \mathrm{~m}^{3} \mathrm{~h}^{-1}$. After screening and grit removal, the wastewater produced flows into a primary clarification basin, where it undergoes an activated sludge process, with partial aerobic stabilisation of the sludge. Finally, the wastewater is subjected to chemical precipitation of phosphorus, and denitrification and chlorination treatments.

The experimental trial was arranged in the field according to a randomised complete block design for the two irrigation treatments (i.e., groundwater, wastewater), each of which was applied as three replications. Each plot had a surface area of $450 \mathrm{~m}^{2}$
( $15 \mathrm{~m}$ wide, $30 \mathrm{~m}$ long), with a sampling area of $20 \mathrm{~m}^{2}$ (2.5 m wide, $8.0 \mathrm{~m}$ long).

A processing tomato crop (Solanum lycopersicum $\mathrm{L}$. [formerlylycopersicon esculentum Mill.] cv. 'Manyla'; an indeterminate growth plant) was transplanted into the experimental field on 12 April, 2012, in double rows that were $250 \mathrm{~cm}$ apart, with $40 \mathrm{~cm}$ spacing between the paired rows, and $30 \mathrm{~cm}$ spacing within each row, which resulted in a theoretical spacing of 2.7 plants $\mathrm{m}^{-2}$. A drip irrigation method was used, with the drip lines placed between each pair of rows, under a black plastic mulching film. The tomato plants were grown vertically, under a net house structure, which was covered with an anti-hail net. This system used nylon threads positioned between the plant collar and iron wires that were arranged longitudinally in the direction of the plant rows, and were fixed to the upper part of the net house, at $2.5 \mathrm{~m}$ from the ground. For each irrigation treatment, the plants were irrigated whenever the soil water deficit in the effective root zone $(0-50 \mathrm{~cm}$ in depth) was $40 \%$ of the total available soil water (Allen et al., 1998). This irrigation limit was assessed by continuous monitoring of the volumetric soil water content, which was carried out using probes that operated in the frequency domain, using frequency domain refractometry. These were placed at $20 \mathrm{~cm}, 30 \mathrm{~cm}$ and $40 \mathrm{~cm}$ in depth, and were installed in each plot prior to transplanting the crop. At each irrigation, the soil water content of each plot was increased to field capacity. The water volume at each irrigation varied from $100 \mathrm{~m}^{3} \mathrm{ha}^{-1}$ to $300 \mathrm{~m}^{3} \mathrm{ha}^{-}$ ${ }^{1}$, depending on the crop growth stage. The seasonal irrigation volume applied was $4,957 \mathrm{~m}^{3} \mathrm{ha}^{-1}$, with a watering interval of about 3 days.

The trial was carried out in a clay loam soil (USDA classification), and Table 1 gives the physicochemical characteristics of this soil at the beginning of the study. The agricultural management practices applied to the tomato crop during the experimental 
trial were those commonly adopted by local farmers, such as for fertilising and for weed and pest control. As vegetable crop rotation was not usually carried out in this agricultural area, the plant-health treatments with pesticides applied to the soil and the plants were particularly numerous.
The tomato fruits were hand harvested at full red maturity stage, four times during the cropping season. This starting in June, and continued to August, at approximately two-week intervals (at 82, 96, 110 and 124 days after transplanting).

Table 1. Initial physico-chemical characteristics of the soil in the experimental field $(0-30 \mathrm{~cm}$ in depth)

\begin{tabular}{lcc}
\hline Characteristic & Unit & Value \\
\hline Sand $(2.0>\emptyset<0.02 \mathrm{~mm})$ & $(\%)$ & $39.2 \pm 0.2$ \\
Loam $(0.02>\varnothing<0.002 \mathrm{~mm})$ & $(\%)$ & $33.1 \pm 0.1$ \\
Clay $(\varnothing<0.002 \mathrm{~mm})$ & $(\%)$ & $28.0 \pm 0.1$ \\
$\mathrm{pH}\left(\right.$ in $\left.\mathrm{H}_{2} \mathrm{O}\right)$ & & $7.9 \pm 0.1$ \\
$\mathrm{EC}$ on 1:2 $(\mathrm{w} / \mathrm{v})$ acqueus soil extract & $\left(\mathrm{d} \mathrm{S} \mathrm{m}^{-1}\right)$ & $0.49 \pm 0.1$ \\
$\mathrm{Ca}^{2+}$ & $\left(\mathrm{mg} \mathrm{kg}^{-1}\right)$ & $4,060 \pm 35$ \\
$\mathrm{Mg}^{2+}$ & $\left(\mathrm{mg} \mathrm{kg}^{-1}\right)$ & $250 \pm 2.5$ \\
$\mathrm{Na}^{+}$ & $\left(\mathrm{mg} \mathrm{kg}^{-1}\right)$ & $856 \pm 10$ \\
$\mathrm{Sodium}^{2}$ adsorption rate & & $3.51 \pm 0.30$ \\
$\mathrm{~K}_{2} \mathrm{O}$ extractable & $\left(\mathrm{mg} \mathrm{kg}^{-1}\right)$ & $730 \pm 9.0$ \\
$\mathrm{NO}_{3}-\mathrm{N}$ & $\left(\mathrm{mg} \mathrm{kg}^{-1}\right)$ & $4.75 \pm 0.4$ \\
$\mathrm{NH}_{4}-\mathrm{N}$ & $\left(\mathrm{mg} \mathrm{kg}^{-1}\right)$ & $7.50 \pm 0.6$ \\
$\mathrm{P}_{2} \mathrm{O}_{5}($ Olsen$)$ & $\left(\mathrm{mg} \mathrm{kg}^{-1}\right)$ & $80.1 \pm 5.0$ \\
Total nitrogen (Kjeldhal) & $(\%)$ & $0.8 \pm 0.3$ \\
Organic matter (Walkley-Black) & $(\%)$ & $1.6 \pm 0.2$ \\
Moisture at field capacity $(-0.03 \mathrm{MPa})$ & $(\%)$ & $30.5 \pm 1.2$ \\
Moisture at wilting point $(-1.5 \mathrm{MPa})$ & $(\%)$ & $15.9 \pm 0.2$ \\
$\mathrm{Bulk}$ density & $\left(\mathrm{Mg} \mathrm{m}^{-3}\right)$ & $1.41 \pm 0.03$ \\
\hline
\end{tabular}

Data are means \pm standard errors $(\mathrm{n}=3)$

\subsection{Climate}

The climate of the area where the trial was carried out is generally of the thermo-Mediterranean-accentuated type, according to the climate maps of the Food and Agriculture Organisation of the United Nations. The temperatures can drop below $0{ }^{\circ} \mathrm{C}$ in winter and exceed peaks of $40{ }^{\circ} \mathrm{C}$ in summer, and the rainfall is unevenly distributed through the year (540 $\left.\mathrm{mm}_{\text {year }}{ }^{-1}\right)$, with it predominantly concentrated in the period from November to February. The annual pan-evaporation rate of Class A is on average $1,573 \mathrm{~mm}$.

The monthly values of the main climate parameters recorded in the course of the 2012 trial are reported 
in Table 2, which were measured by a weather station and stored by a data logger (Campbell Scientific, USA), both of which were located near the site of the experimental trial. During the growing season, the weather was characterised according to the mean maximum and minimum temperatures of $29.4^{\circ} \mathrm{C}$ and $15.8{ }^{\circ} \mathrm{C}$, respectively. The summer season was very dry, with the effective rainfall for the tomato crop mainly occurring during the first stage of the growing season (April, $67 \mathrm{~mm}$ ). The total Class A pan-evaporation was $797 \mathrm{~mm}$.

Table 2. Main climatic parameters recorded during the growing season of the tomato crops (2012)

\begin{tabular}{lccccccc}
\hline Month & \multicolumn{7}{c}{ Climatic parameter } \\
& $\mathbf{T}_{\text {min }}$ & $\mathbf{T}_{\text {max }}$ & $\mathbf{R H}_{\text {min }}$ & $\mathbf{R H}_{\mathbf{m a x}}$ & $\mathbf{P}$ & $\mathbf{W s}$ & $\mathbf{E v}$ \\
& $\left({ }^{\circ} \mathbf{C}\right)$ & $\left({ }^{\circ} \mathbf{C}\right)$ & $\mathbf{( \% )}$ & $\mathbf{( \% )}$ & $(\mathbf{m m})$ & $\left(\mathbf{m ~ s}^{\mathbf{- 1}}\right)$ & $(\mathbf{m m})$ \\
\hline April & 8.5 & 20.1 & 51.7 & 95.6 & 67.0 & 2.30 & 86.9 \\
May & 11.6 & 25.0 & 36.6 & 82.8 & 28.0 & 2.42 & 137.5 \\
June & 17.9 & 33.0 & 27.3 & 71.1 & 0.0 & 2.72 & 197.9 \\
July & 20.8 & 34.4 & 30.6 & 77.1 & 8.4 & 2.43 & 195.3 \\
August & 20.2 & 34.5 & 29.4 & 81.4 & 5.0 & 2.10 & 176.5 \\
\hline Growing season & 15.8 & 29.4 & 35.1 & 81.6 & 108.4 & 2.40 & 794.1 \\
\hline
\end{tabular}

$\mathrm{T}_{\min }, \mathrm{T}_{\max }$, monthly minimum, maximum air temperature; $\mathrm{RH}_{\min }, \mathrm{RH}_{\max }$, monthly minimum, maximum relative air humidity; $\mathrm{P}$, total precipitation; Ws, monthly mean wind speed; $\mathrm{E}_{\mathrm{v}}$, Total "class A" pan-evaporation

\subsection{Water sampling and analysis}

Irrigation water samples of the groundwater and wastewater were collected and analysed in triplicate at monthly intervals on five dates (28 May, 13 June, 2 and 17 July, 29 August, 2012). Three samples from both irrigation sources were collected in sterile 1000 $\mathrm{ml}$ glass bottles and transported in an ice chest to the laboratory for the physico-chemical analytical determination. In the laboratory, the collected samples were kept in the refrigerator at $4{ }^{\circ} \mathrm{C}$ and examined within $24 \mathrm{~h}$ of collection. The parameters measured were: $\mathrm{pH}$, electrical conductivity (EC), TSS, sodium $\left(\mathrm{Na}^{+}\right)$, potassium $\left(\mathrm{K}^{+}\right)$, calcium $\left(\mathrm{Ca}^{2+}\right)$, magnesium $\left(\mathrm{Mg}^{2+}\right)$, sodium adsorption ratio (SAR), chemical oxygen demand (COD), biological oxygen demand over five days $\left(\mathrm{BOD}_{5}\right)$, ammonium-nitrogen $\left(\mathrm{NH}_{4}-\mathrm{N}\right)$, nitrate-nitrogen $\left(\mathrm{NO}_{3}-\mathrm{N}\right)$, phenols, carbonates $\left(\mathrm{CO}_{3}^{-}\right)$, bicarbonates $\left(\mathrm{HCO}_{3}^{-}\right)$, phosphates $\left(\mathrm{PO}_{4}^{-} \mathrm{P}\right)$, sulphates, chlorides and fluorides. These analyses were carried out according to standard Italian methods, which refer to the common international methods (APHAAWWA-EF, 2005).

The $\mathrm{pH}$ was measured with a GLP 22+ $\mathrm{pH}$ and ion meter (Crison), and the EC with a GLP $31+$ electrical conductivity meter (Crison). TSS were determined after filtration of the water samples through $0.45 \mu \mathrm{m}$ membrane filters using a vacuum system. The $\mathrm{Na}^{+}$, $\mathrm{K}^{+}, \mathrm{Ca}^{2+}, \mathrm{Mg}^{2+}$, sulphate, chloride and fluoride levels were determined by ion-exchange chromatography (Dionex ICS-1100, Dionex Corporation, Sunnyvale, CA, USA). 


\subsection{Soil sampling and analysis}

Soil samples for chemical analysis were collected at each experimental plot before the tomato transplanting (on 16 March) and during the tomato crop cycle, for each plot and on seven dates (14 and 28 May, 13 June, 2 and 17 July, 29 August, 9 September, 2012; from a $30-\mathrm{cm}$ layer, as the effective root density zone), and for fungal analysis on 16 March (15-cm and 30-cm layers) and 28 May, 7 July, 6 August and 4 September, 2012 (30-cm layer). All of these samples were collected in the areas wetted by the drippers, using a soil auger.

The soil samples were air dried and passed through a 2-mm sieve, and then the chemical properties were determined. Soil subsamples from each depth were analysed for $\mathrm{pH}, \mathrm{Na}^{+}, \mathrm{Ca}^{2+}, \mathrm{Mg}^{2+}$, SAR, $\mathrm{EC}, \mathrm{NO}_{3}-\mathrm{N}$, $\mathrm{NH}_{4}-\mathrm{N}$, available phosphorus $\left(\mathrm{P}_{2} \mathrm{O}_{5}\right)$, potassium $\left(\mathrm{K}_{2} \mathrm{O}\right)$ and organic matter (OM). $\mathrm{EC}$ and $\mathrm{pH}$ were measured in 1:2(w/v) and 1:2.5 (w/v) aqueous soil extracts, respectively. $\mathrm{P}_{2} \mathrm{O}_{5}$ was determined using the sodium bicarbonate method (Olsen et al., 1954). The soluble $\mathrm{Na}^{+}, \mathrm{K}^{+}, \mathrm{Ca}^{2+}$ and $\mathrm{Mg}^{2+}$ were analysed using an atomic absorption spectrometer (model 2380, Perkin-Elmer). The organic carbon of the soil was determined by oxidation with potassium dichromate titration of $\mathrm{FeSO}_{4}$, according to the Walkley-Black method (1934). The OM was calculated by multiplying the percentage of organic carbon by the factor 1.724 . The soluble $\mathrm{NO}_{3}-\mathrm{N}$ and $\mathrm{NH}_{4}-\mathrm{N}$ were determined according to Keeney and Nelson (1982).

Fungal analysis of the soil was carried out according to standard methods (Allievi and Quaroni, 2002). In particular, each subsample of soil was finely crushed and left to dry in the air, and then an aliquot of $10 \mathrm{~g}$ was taken and kept in suspension (by vigorous stirring for $5 \mathrm{~min}$ ) in $90 \mathrm{ml}$ sterile distilled water. This suspension was taken through decimal dilutions $(1: 100,1: 1000$ and 1:10,000), from which aliquots of $0.1 \mathrm{ml}$ were spread in Petri dishes containing agar potato sucrose supplemented with $500 \mathrm{ppm}$ streptomycin sulphate, and modified pentachloronitrobenzene medium (Papavizas, 1967). After 5 days and 10 days of incubation at $23 \pm 2$ ${ }^{\circ} \mathrm{C}$, the resulting fungal colonies were counted. These fungal colonies were purified for identification and morphological characterisation. The densities of the colonies are expressed as $\mathrm{CFU} \mathrm{g}^{-1}$ dry soil.

\subsection{Tomato fruit sampling and analysis}

At each harvest, only the ripe fruit were picked. Then the marketable yield $\left(\mathrm{Mg} \mathrm{ha}^{-1}\right)$ and the marketable fruit per plant $\left(\mathrm{kg} \mathrm{plant}^{-1}\right)$ were determined. Also, on a sample of 10 marketable fruit from each plot, the following parameters were measured: mean diameter of fruit $(\mathrm{cm})$, dry matter ( $\%$ fresh weight), colour index, $\mathrm{pH}$, fresh tomato soluble solids content ( $\left.{ }^{\circ} \mathrm{Brix}\right)$, and $\mathrm{NO}_{3}-\mathrm{N}$ (mg $100 \mathrm{~g}^{-1}$ fresh weight). In addition, fungal analysis was carried out, and the colony densities of were expressed as $\mathrm{CFU} \mathrm{g}^{-1}$ fresh weight.

\subsection{Statistical analysis}

All of the data were processed statistically using analysis of variance (ANOVA), followed by T-tests or Tukey's tests when significant effects were detected ( $P$ $\leq 0.05$ ). Data are expressed as means \pm standard error.

\section{Results}

\subsection{Chemical characteristics of the groundwater and wastewater}

Table 3 gives the data for the irrigation wastewater and groundwater characteristics, which were measured five times during the tomato crop cycle, and the parameter thresholds for wastewater reuse that are allowed according to Italian law (Decree of the Ministry for the Environment, No. 152, 2006). 
The physical and chemical characteristics varied considerably between the two applied irrigation water types. As expected, compared to the groundwater, the levels of most of the chemical parameters were significantly higher in the wastewater, including for $\mathrm{EC}, \mathrm{Na}^{+}, \mathrm{K}^{+}, \mathrm{Ca}^{2+}, \mathrm{Mg}^{2+}$, TSS, SAR, COD, $\mathrm{BOD}_{5}$, $\mathrm{NH}_{4}-\mathrm{N}$, phenols, $\mathrm{PO}_{4}-\mathrm{P}$ and chlorides. However, in the wastewater, all of these measured parameters remained below the Italian limits allowed for agriculture reuse (Decree of the Ministry for the Environment, No. 152, 2006), except for TSS, $\mathrm{BOD}_{5}$ and phenols, which were slightly above these limits. It is worth noting that the $\mathrm{NO}_{3}-\mathrm{N}$ content was very high in the groundwater $(29.1$ $\left.\mathrm{mg} 1^{-1}\right)$ compared to the wastewater $\left(1.20 \mathrm{mg}^{-1}\right)$. This excess level of nitrates in the local groundwater is due to excessive levels of nitrogen fertilisers commonly applied to the vegetable crops by the local farmers. This has also been reported in a local resolution (Decree of the Apulia Region, $N^{\circ} 2036,2005$ ), which has classified the zone of our experimental field as a nitrate-vulnerable area. This high $\mathrm{NO}_{3}-\mathrm{N}$ in the groundwater represents an important source of nutrient for the plants, but the farmers do not take this into account in their fertilising practices, and accordingly, nitrate leaching problems and groundwater pollution processes have occurred.

Table 3. Physical and chemical properties of the irrigation waters used in the present study, and the Italian threshold values for wastewater reuse in irrigation (Decree of the Ministry for the Environment, No. 152, 2006).

\begin{tabular}{|c|c|c|c|c|}
\hline \multirow[t]{2}{*}{ Parameter } & \multirow{2}{*}{$\begin{array}{l}\text { MD152/2006 } \\
\text { limit }\end{array}$} & \multicolumn{2}{|c|}{ Irrigation water } & \multirow[t]{2}{*}{$\mathbf{p}$} \\
\hline & & Groundwater & Wastewater & \\
\hline $\mathrm{pH}$ & $6.0-9.5$ & $7.63 \pm 0.10$ & $7.76 \pm 0.09$ & ns \\
\hline $\mathrm{EC}\left(\mathrm{dS} \mathrm{m^{-1 }}\right)$ & 3 & $0.69 \pm 0.05$ & $2.18 \pm 0.12$ & $\leq 0.05$ \\
\hline $\operatorname{TSS}\left(\mathrm{mg} \mathrm{l}^{-1}\right)$ & 10 & $3.26 \pm 0.34$ & $16.21 \pm 2.24$ & $\leq 0.05$ \\
\hline $\mathrm{Na}^{+}\left(\mathrm{mg} \mathrm{l}^{-1}\right)$ & & $33.53 \pm 0.54$ & $219.85 \pm 6.05$ & $\leq 0.05$ \\
\hline $\mathrm{K}^{+}\left(\mathrm{mg} \mathrm{l}^{-1}\right)$ & & $9.35 \pm 0.16$ & $41.17 \pm 1.96$ & $\leq 0.05$ \\
\hline $\mathrm{Ca}^{2+}\left(\mathrm{mg} \mathrm{l}^{-1}\right)$ & & $52.82 \pm 3.23$ & $85.27 \pm 1.24$ & $\leq 0.05$ \\
\hline $\mathrm{Mg}^{2+}\left(\mathrm{mg} \mathrm{l}^{-1}\right)$ & & $8.90 \pm 0.20$ & $10.25 \pm 0.12$ & $\leq 0.05$ \\
\hline SAR & 10 & $1.13 \pm 0.03$ & $5.99 \pm 0.18$ & $\leq 0.05$ \\
\hline $\operatorname{COD}\left(\mathrm{mg} \mathrm{1-}{ }^{1}\right)$ & 100 & $18.44 \pm 1.62$ & $39.73 \pm 2.78$ & $\leq 0.05$ \\
\hline $\mathrm{BOD}_{5}\left(\mathrm{mg} \mathrm{l}^{-1}\right)$ & 20 & $9.33 \pm 1.03$ & $21.58 \pm 1.62$ & $\leq 0.05$ \\
\hline $\mathrm{NH}_{4}-\mathrm{N}\left(\mathrm{mg} \mathrm{l}^{-1}\right)$ & 2 & $0.04 \pm 0.00$ & $0.39 \pm 0.10$ & $\leq 0.05$ \\
\hline $\mathrm{NO}_{3}-\mathrm{N}\left(\mathrm{mg} \mathrm{l}^{-1}\right)$ & & $29.06 \pm 1.67$ & $1.20 \pm 0.32$ & $\leq 0.05$ \\
\hline Phenols ( $\mathrm{mg} \mathrm{l}^{-1}$ ) & 0.1 & $0.07 \pm 0.00$ & $0.13 \pm 0.00$ & $\leq 0.05$ \\
\hline $\mathrm{CO}_{3}{ }^{2-}\left(\mathrm{mg} \mathrm{l}^{-1}\right)$ & & $171.50 \pm 5.32$ & $193.67 \pm 11.89$ & $\mathrm{~ns}$ \\
\hline $\mathrm{HCO}_{3}^{-}\left(\mathrm{mg} \mathrm{l}^{-1}\right)$ & & $257.89 \pm 2.85$ & $254.23 \pm 21.57$ & $\mathrm{~ns}$ \\
\hline $\mathrm{PO}_{4}-\mathrm{P}\left(\mathrm{mg} \mathrm{l}^{-1}\right)$ & 10 & $0.10 \pm 0.01$ & $0.29 \pm 0.02$ & $\leq 0.05$ \\
\hline $\mathrm{SO}_{4}^{-}\left(\mathrm{mg} \mathrm{l}^{-1}\right)$ & 500 & $30.17 \pm 1.30$ & $31.84 \pm 0.85$ & $\mathrm{~ns}$ \\
\hline
\end{tabular}

Data are means \pm standard errors $(n=15 ; 3$ replicates $\times 5$ dates $)$. ns, not significant

For parameter abbreviations, see main text 


\subsection{Soil chemical properties}

The effects of the two types of irrigation water (i.e., groundwater, wastewater) on the soil chemical properties from the analyses of the samples collected at a 30-cm depth are given in Table 4 .

In agreement with the characteristics of the irrigation water applied, compared with the soil watered with groundwater, the soil of the plots watered with the wastewater had significantly higher levels of $\mathrm{Na}^{+}$, EC, SAR and $\mathrm{NH}_{4}-\mathrm{N}$. For the soil $\mathrm{pH}$, no significant differences were seen between these irrigation treatments. The mean soil $\mathrm{pH}$ during the tomato crop cycle in both of the water treatments increased slightly ( $\mathrm{pH} 8.18$ ) with respect to the initial value $(\mathrm{pH} 7.9)$, probably due to the accumulation in the soil of basic cations due to the fertilising.

Table 4. Main parameters measured on soil samples collected at 30-cm soil depth in the test field irrigated with groundwater and wastewater.

\begin{tabular}{|c|c|c|c|c|c|c|c|c|c|c|c|}
\hline Treatment & $\begin{array}{c}\mathrm{pH} \\
\text { (in } \mathrm{H}_{2} \mathrm{O} \text { ) }\end{array}$ & $\begin{array}{c}\mathrm{Na}^{+} \\
\left(\mathrm{mg} \mathrm{kg}^{-1}\right)\end{array}$ & $\begin{array}{c}\mathrm{K}^{+} \\
\left(\mathrm{mg} \mathrm{kg}^{-1}\right)\end{array}$ & $\begin{array}{c}\mathrm{Ca}^{2+} \\
\left(\mathrm{mg} \mathrm{kg}^{-1}\right)\end{array}$ & $\begin{array}{c}\mathrm{Mg}^{2+} \\
\left(\mathrm{mg} \mathrm{kg}^{-1}\right)\end{array}$ & $\begin{array}{c}E C \\
\left(\mathrm{dS} \mathrm{m}^{-1}\right)\end{array}$ & SAR & $\begin{array}{c}\mathrm{NO}_{3}-\mathrm{N} \\
\left(\mathrm{mg} \mathrm{kg}^{-1}\right)\end{array}$ & $\begin{array}{c}\mathrm{NH}_{4}-\mathrm{N} \\
\left(\mathrm{mg} \mathrm{kg}^{-1}\right)\end{array}$ & $\begin{array}{c}\mathrm{P}_{2} \mathrm{O}_{5} \\
\left(\mathrm{mg} \mathrm{kg}^{-1}\right)\end{array}$ & $\begin{array}{l}\text { OM } \\
(\%)\end{array}$ \\
\hline Groundwater & $8.30 \pm 0.11$ & $705 \pm 70 b$ & $762 \pm 30$ & $4152 \pm 50$ & $290 \pm 28$ & $0.44 \pm 0.11 \mathrm{~b}$ & $2.8 \pm 0.2 b$ & $10.02 \pm 0.8 \mathrm{~b}$ & $14.7 \pm 2.2 \mathrm{~b}$ & $147.5 \pm 17.0$ & $1.97 \pm 0.1$ \\
\hline Wastewater & $8.06 \pm 0.11$ & $1039 \pm 80 \mathrm{a}$ & $790 \pm 46$ & $4197 \pm 61$ & $306 \pm 30$ & $1.05 \pm 0.14 \mathrm{a}$ & $3.5 \pm 0.3 \mathrm{a}$ & $12.83 \pm 0.9 \mathrm{a}$ & $21.2 \pm 3.1 \mathrm{a}$ & $181.4 \pm 19.6$ & $1.99 \pm 0.1$ \\
\hline
\end{tabular}

Data are means \pm standard error $(\mathrm{n}=21)$

Values in the same column followed by different letters are significantly different $(\mathrm{T}$-test, $\mathrm{P} \leq 0.05)$

For parameter abbreviations, see main text

On the contrary, although the concentrations of $\mathrm{K}^{+}$, $\mathrm{Ca}^{2+}, \mathrm{Mg}^{2+}$ and $\mathrm{PO}_{4}-\mathrm{P}$ were significantly greater in the wastewater than the groundwater, their levels in the soil were not significantly different for the two water treatments. The mean EC in groundwaterirrigated plots $\left(0.44 \mathrm{dS} \mathrm{m}^{-1}\right)$ was similar to that at the beginning of the experiment $\left(0.49 \mathrm{dS} \mathrm{m}^{-1}\right)$, while the highly significant increase in the $\mathrm{EC}$ with the wastewater $\left(1.05 \mathrm{dS} \mathrm{m}^{-1}\right)$ appears to be due to the higher concentration of salts in the wastewater.

Considering that the $\mathrm{NO}_{3}-\mathrm{N}$ levels were higher in the groundwater than the wastewater, the soil irrigated with the groundwater would be expected to have higher $\mathrm{NO}_{3}-\mathrm{N}$ than that irrigated with the wastewater. Instead, the levels of $\mathrm{NO}_{3}-\mathrm{N}$ in the irrigated soils were slightly higher for the wastewater than the groundwater treatment. This might be due to the water movement pattern along the soil profile, which might have caused $\mathrm{NO}_{3}-\mathrm{N}$ leaching out of the upper $0-\mathrm{cm}$ to $30-\mathrm{cm}$ soil layer, and the higher plant uptake from the soil solution, or potentially to nitrification of the $\mathrm{OM}$ in the wastewater. As also indicated below, the groundwater treatment resulted in a greater yield $\left(82.88 \mathrm{Mg} \mathrm{ha}^{-1}\right)$, albeit not very much more than the wastewater treatment $\left(79.05 \mathrm{Mg} \mathrm{ha}^{-1}\right)$, and more water uptake and transpiration of tomato plants probably occurred. In addition, the $\mathrm{NO}_{3}-\mathrm{N}$ levels in the tomatoes with the groundwater treatment were comparable to those with the wastewater treatment.

However, the wastewater-irrigated soil showed higher BOD, COD and TSS, and no differences of the mean soil OM levels were noted between the treatments. The increase in OM was probable temporary, as this is rapidly mineralised through the abundant microbial activity on the OM supplied by the wastewater (Di Serio et al., 2008). 
3.3. Effects of groundwater and wastewater on soilborne fungi

The data from the soil analysis of the soil-borne fungi show that the total fungal CFU detected in the soil samples taken at the two soil depths $(15$ and $30 \mathrm{~cm})$ before the tomato transplanting (on 16 March), and therefore before the irrigation was started, were not significantly different $\left(1.75 \times 10^{4} \pm 6.50 \times 10^{3}, 3.05\right.$ $\times 10^{4} \pm 1.95 \times 10^{4} \mathrm{CFU} \mathrm{g}^{-1}$ soil, respectively). The total fungi measured at $30-\mathrm{cm}$ soil depth on the four sampling dates during the tomato crop cycle under the two irrigation treatments are illustrated in Figure 1. The fungal counts basically increased for the wastewater irrigation treatment during the trial period, while in the plot irrigated with the groundwater, these remained more or less constant.

In particular, there were significant differences between the irrigation treatments on the samples of the last period of the tomato cycle. Indeed, the total microbial biomass in wastewater-irrigated soil collected on 6 August and 4 September, 2012, were significantly greater $\left(5.45 \times 10^{4} \pm 4.5 \times 10^{3}, 1.30 \times 10^{5}\right.$ $\pm 3.0 \times 10^{4} \mathrm{CFU} \mathrm{g}{ }^{-1}$ soil, respectively) than in the groundwater-irrigated plots $\left(3.75 \times 10^{4} \pm 7.50 \times 10^{3}\right.$, $3.05 \times 10^{4} \pm 4.11 \times 10^{3} \mathrm{CFU} \mathrm{g}^{-1}$ soil, respectively). The data for the effects of the irrigation treatments on the mycoflora composition of the soil during the trial are given in Table 5. From a qualitative point of view, very high differences were noted for the fungal species between the two soil layers (0-15 and $15-30 \mathrm{~cm}$ ) on $16 \mathrm{March}$, and so before the crop transplanting. The upper layer had a mycoflora that was composed of about $90 \%$ saprophytic fungi (e.g., Penicillium expansum, Aspergillus spp.), with low levels (2.9\%) of phytopathogens, including Fusarium oxysporum. This fungus was not found in the deeper, $15-\mathrm{cm}$ to $30-\mathrm{cm}$ soil layer.

Table 5. Soil-borne fungi detected in the soil from the different sampling dates during the present study

\begin{tabular}{|c|c|c|c|c|c|c|c|c|c|c|}
\hline \multirow[t]{4}{*}{ Fungal species } & \multicolumn{10}{|c|}{ Fungal levels detected according to sampling date and soil depth/irrigation treatment (\%, within each condition) } \\
\hline & \multirow{2}{*}{\multicolumn{2}{|c|}{$\begin{array}{c}16 \mathrm{March}^{\mathrm{a}} \\
\text { Soil depth (cm) }\end{array}$}} & \multicolumn{2}{|c|}{28 May $^{\text {b }}$} & \multicolumn{2}{|c|}{7 July $^{b}$} & \multicolumn{2}{|c|}{6 August $^{\mathrm{b}}$} & \multicolumn{2}{|c|}{4 September $^{\mathrm{b}}$} \\
\hline & & & \multirow[t]{2}{*}{ Groundwater } & \multirow[t]{2}{*}{ Wastewater } & \multirow[t]{2}{*}{ Groundwater } & \multirow[t]{2}{*}{ Wastewater } & \multirow[t]{2}{*}{ Groundwater } & \multirow[t]{2}{*}{ Wastewater } & \multirow[t]{2}{*}{ Groundwater } & \multirow[t]{2}{*}{ Wastewater } \\
\hline & 15 & 30 & & & & & & & & \\
\hline Penicillium italicum & & & $16.0 \pm 0.2$ & $16.7 \pm 0.2$ & $30.9 \pm 0.2$ & $35.6 \pm 0.3$ & $16.0 \pm 0.3$ & $28.3 \pm 0.3$ & $18.6 \pm 0.2$ & $30.8 \pm 0.3$ \\
\hline Penicillium expansum & $48.6 \pm 0.5$ & $46.7 \pm 0.7$ & & $16.7 \pm 0.3$ & & & $9.8 \pm 0.2$ & & $8.5 \pm 0.5$ & $42.3 \pm 0.3$ \\
\hline Aspergillus spp. & $40.0 \pm 0.3$ & $46.7 \pm 0.3$ & $16.1 \pm 0.7$ & $20.8 \pm 0.4$ & $9.5 \pm 0.5$ & & $16.4 \pm 0.4$ & $36.1 \pm 0.1$ & $18.6 \pm 0.2$ & \\
\hline Aspergillus ustus & & $6.7 \pm 0.3$ & & & & & & & & \\
\hline Aspergillus niger & & & & & $11.9 \pm 0.2$ & $29.1 \pm 0.1$ & $5.0 \pm 0.5$ & $15.1 \pm 0.2$ & $5.1 \pm 0.1$ & \\
\hline Fusarium spp. & $5.7 \pm 0.3$ & & $28.0 \pm 0.4$ & $16.7 \pm 0.3$ & & & & & & \\
\hline Fusarium oxysporum & $3.0 \pm 0.2$ & & $28.0 \pm 0.1$ & $29.2 \pm 0.2$ & $28.6 \pm 0.2$ & $25.6 \pm 0.6$ & $23.5 \pm 0.5$ & $4.3 \pm 0.2$ & $20.3 \pm 0.3$ & $3.9 \pm 0.3$ \\
\hline Stemphylium spp. & $2.9 \pm 0.3$ & & & & & & $28.3 \pm 0.3$ & & $27.1 \pm 0.2$ & \\
\hline Trichoderma spp. & & & $12.0 \pm 0.5$ & & & & & $12.2 \pm 0.2$ & & $15.4 \pm 0.4$ \\
\hline Sclerotinia minor & & & & & $16.7 \pm 0.3$ & $3.2 \pm 0.2$ & $1.0 \pm 0.3$ & $4.0 \pm 0.1$ & $1.7 \pm 0.3$ & $7.7 \pm 0.4$ \\
\hline Rhizopus spp. & & & & & $2.4 \pm 0.4$ & $3.2 \pm 0.1$ & & & & \\
\hline Echinobotryum spp. & & & & & & $3.2 \pm 0.2$ & & & & \\
\hline
\end{tabular}

Data are means \pm standard errors $(n=3)$. Only those fungi found for each sampling are indicated

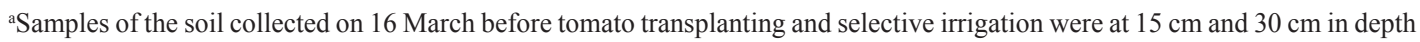

${ }^{\mathrm{b}} \mathrm{All}$ samples of the soil collected only at $30 \mathrm{~cm}$ in depth 


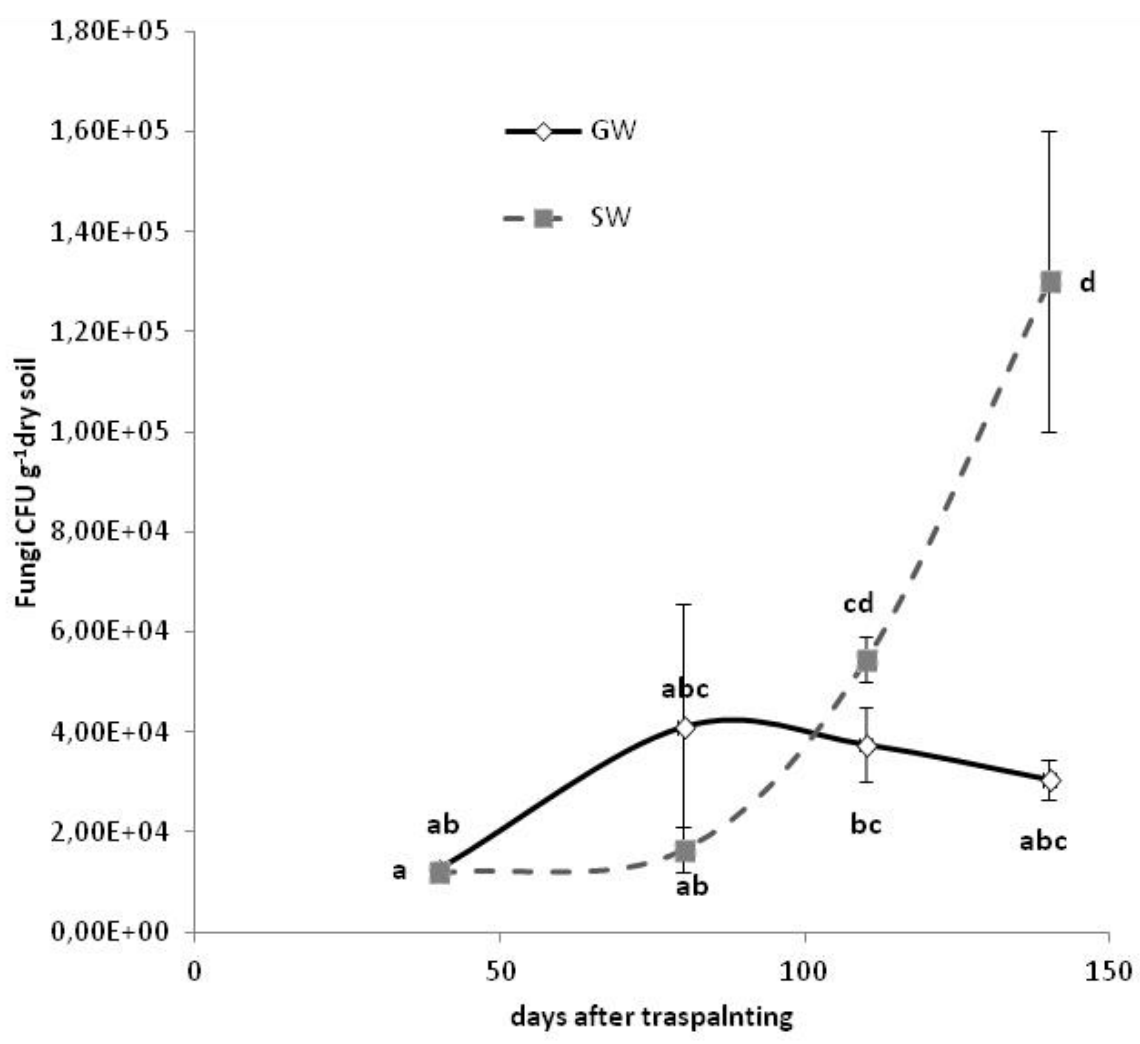

Figure 1. Total fungi detected in the soil samples at $30 \mathrm{~cm}$ in depth for the different sampling dates during the tomato crop cycle following irrigation with groundwater and secondary treated wastewater (as indicated). Data are means \pm standard error ( $\mathrm{n}=3$ ). The significant interactions between the treatments and sampling dates are indicated by different letters $(\mathrm{P} \leq 0.05$; Tukey's test).

During the tomato crop cycle, the composition of the mycoflora was different among the soil samples collected at $30 \mathrm{~cm}$ in depth on the different dates. In particular, for both irrigation treatments, the presence of Fusarium spp. was detected, in contrast with what was observed in the same soil layer prior to transplanting, where the fungus was totally absent. Later, the load of Fusarium spp. in the $30-\mathrm{cm}$ soil layer irrigated with the groundwater was almost constant over time, while in the soil irrigated with the wastewater, this load of Fusarium spp. progressively decreased, down to around $4 \%$ at the last samplings of 6 August and 4 September, 2012. Conversely, higher colonisation of saprophytic species was seen, such that in the soil irrigated with the wastewater, Trichoderma spp. also appeared, which is a known antagonistic agent of root pathogens.

The effects of this situation in the soil also occurred in the further tomato crop in the following year (2013) in the same field at the beginning of the crop cycle, when the plants suffered from an attack that was, however, different between the two irrigation treatments. 
Indeed, the levels of dead plants collected on 28 May, 2013 , was higher with the groundwater irrigation $(8.3 \% \pm 0.5 \%)$ than with the wastewater irrigation $(2.4 \% \pm 0.4 \%)$.

3.4. Microbiological analysis and productive characteristics of the tomato fruit

Table 6 shows the fungal isolation from the tomato plants obtained for two dates during the crop cycle. These indicated the presence of Fusarium spp. from roots and stems of tomato plants under both treatments at the sampling of 17 July, while at the sampling of 9 September they were absent for the wastewater treatment.
Table 7 shows the physical and chemical traits of the tomato fruit with respect to the two experimental irrigation water types. Although the marketable yield was slightly higher in the groundwater $(82.88 \mathrm{Mg}$ ha 1) than the wastewater $\left(79.05 \mathrm{Mg} \mathrm{ha}^{-1}\right)$, there was no significant difference between these two irrigation treatments. Also, the other quanti-qualitative parameters of tomato yield did not show differences between the treatments, except for $\mathrm{pH}$, which was lower in wastewater treatment (4.35) compared with groundwater treatment (4.54). Finally, due to the high concentration of $\mathrm{NO}_{3}-\mathrm{N}$ in the groundwater applied, this was higher in the fruit for the groundwater treatment $\left(1.32 \mathrm{mg} 100 \mathrm{ml}^{-1}\right)$ than for the wastewater

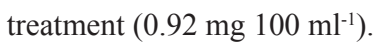

Table 6. Fungi isolated from tomato plants

\begin{tabular}{|c|c|c|c|c|}
\hline \multirow[t]{2}{*}{ Location } & \multicolumn{2}{|c|}{17 July } & \multicolumn{2}{|c|}{9 September } \\
\hline & Groundwater & Wastewater & Groundwater & Wastewater \\
\hline Roots & $\begin{array}{c}\text { Fusarium } \\
\text { solani }\end{array}$ & $\begin{array}{c}\text { Pyernocheta } \\
\text { spp. }\end{array}$ & Fusarium spp. & Phoma spp. \\
\hline & $\begin{array}{c}\text { Plectosporium } \\
\text { spp. }\end{array}$ & $\begin{array}{l}\text { Fusarium } \\
\text { spp. } \\
\text { Phoma spp. }\end{array}$ & Phoma spp. & \\
\hline $\begin{array}{l}\text { Plant } \\
\text { collar }\end{array}$ & - & - & Fusarium spp. & - \\
\hline & & & Phoma spp. & - \\
\hline Stem & - & $\begin{array}{c}\text { Fusarium } \\
\text { spp. }\end{array}$ & - & - \\
\hline
\end{tabular}


Table 7. Effects of the groundwater and the secondary treated agro-industrial wastewater applied as irrigation on the quanti-qualitative traits of the tomato fruit.

\begin{tabular}{|c|c|c|c|c|c|c|c|c|}
\hline Treatment $^{\S}$ & $\begin{array}{c}\text { MY } \\
\left(\mathrm{Mg} \mathrm{ha}^{-1}\right)\end{array}$ & $\begin{array}{c}\text { MYP } \\
\text { (kg plant }^{-1)}\end{array}$ & $\begin{array}{c}\text { DM } \\
(\% \text { FM) }\end{array}$ & $\begin{array}{l}\text { MD } \\
\text { (cm) }\end{array}$ & CI & $\begin{array}{c}\text { SSC } \\
\left({ }^{\circ} \text { Brix }\right)\end{array}$ & pH & $\begin{array}{c}\mathrm{NO}_{3}-\mathrm{N} \\
\left(\mathrm{mg} 100 \mathrm{~g}^{-1}\right)\end{array}$ \\
\hline Groundwater & $82.88 \pm 9.47$ & $3.06 \pm 0.29$ & $7.44 \pm 0.11$ & $4.22 \pm 0.32$ & $1.03 \pm 0.03$ & $5.73 \pm 0.12$ & $4.54 \pm 0.04 a$ & $1.32 \pm 0.10 \mathrm{a}$ \\
\hline Wastewater & $79.05 \pm 4.76$ & $2.93 \pm 0.15$ & $7.52 \pm 0.21$ & $4.44 \pm 0.04$ & $0.97 \pm 0.04$ & $5.53 \pm 0.10$ & $4.35 \pm 0.04 b$ & $0.92 \pm 0.06 \mathrm{~b}$ \\
\hline
\end{tabular}

Data are means \pm standard error. MY, marketable yield; MYP, marketable fruit per plant; DM; dry matter; FM, fresh matter; MD, mean diameter $(n=162 ; 3$ replicates $\times 54$ plants/plot $)$. Cl, colour index; $\mathrm{NO}_{3}-\mathrm{N}$, nitrate content $(\mathrm{n}=30 ; 3$ replicates $\times 10$ fruit/plot). Values followed by different letters in each column are significantly different $(\mathrm{P} \leq 0.05$; T-test)

\section{Discussion}

All of the physical and chemical characteristics (i.e., $\mathrm{EC}, \mathrm{Na}^{+}, \mathrm{K}^{+}, \mathrm{Ca}^{2+}, \mathrm{Mg}^{2+}$, TSS, SAR, COD, $\mathrm{BOD}_{5}, \mathrm{NH}_{4}-\mathrm{N}$, phenols, $\mathrm{PO}_{4}-\mathrm{P}$ and chlorides) were significantly higher in the wastewater than the groundwater, although only TSS, $\mathrm{BOD}_{5}$ and phenols were slightly above the Italian limits allowed for agriculture reuse. However, these do not appear to be limiting factors for wastewater reuse, because these OM-related parameters are important from the agronomic point of view. This has been indicated by some studies that have used simplified treatments that skipped the biological processes for saving the agronomic potential of the $\mathrm{OM}$ and nutrients in the urban wastewater after tertiary treatment (Lopez et al., 2006). With regard to the constant presence of fertilisers in the wastewater, such as for phosphorus and potassium, their supply with the irrigation is favourable for plant nutrition.

In agreement with the characteristics of the irrigation water applied, compared with the soil watered with groundwater, the soil of the plots watered with the wastewater had significantly higher levels of $\mathrm{Na}^{+}, \mathrm{EC}$, $\mathrm{SAR}$ and $\mathrm{NH}_{4}-\mathrm{N}$. Due to the higher concentration of salts in the wastewater there was a highly significant increase in the $\mathrm{EC}$, although the value $\left(1.05 \mathrm{dS} \mathrm{m}^{-1}\right)$ still remained below the salinity threshold (4.00 dS $\mathrm{m}^{-1}$ ) (Giardini, 1992). The significant increase in the SAR in the wastewater-irrigated soil was probably due to $\mathrm{Na}^{+}$accumulation in the root zone, and to reduced water infiltration rate, which negatively affects the $\mathrm{Na}^{+}$transport to the deeper layers (Bedbabis et al., 2014). However, all of the measured SARs were significantly below the limit for a soil to be considered sodic (SAR 15).

Albeit that they were slightly higher, the values of $\mathrm{K}^{+}, \mathrm{Ca}^{2+}, \mathrm{Mg}^{2+}$ and $\mathrm{PO}_{4}-\mathrm{P}$ in the soil irrigated with wastewater would suggest that there were fertilising effects, as has been indicated in prevision studies in field experiments using solid waste or irrigation with treated wastewaters (Mojid et al., 2012; Chrysargyris and Tzortzakis, 2015).

With regard to the effects on soil-borne fungi, there was a significant increase in the total microbial biomass in the wastewater-irrigated soil. This increase appears to be related to the higher TSS and phenols in the irrigation wastewater compared to the groundwater. The readily available carbon of the wastewater treatment is an important substrate for stimulation of the development of microflora, and especially of fungi. With regard to this, in other studies carried out on the use of olive-mill wastewater that is characterised by high contents of $\mathrm{OM}$ and 
phenols, an increasing microbial biomass was also observed in the soil (Di Serio et al., 2008; Saadi et al., 2007). Indeed, changes have been found in soil bacterial and fungal communities in such treated soils (Tardioli et al., 1977).

During the tomato crop cycle, the composition of the mycoflora of the soil was different between the two irrigation treatments. In particular, the load of Fusarium spp. in the $30-\mathrm{cm}$ soil layer irrigated with the groundwater was almost constant over time, while in the soil irrigated with the wastewater, this load of Fusarium spp. progressively decreased. Conversely, higher colonisation of saprophytic species (Trichoderma spp.), an antagonistic agent of root pathogens, was seen in the soil irrigated with the wastewater.

One of the different mechanisms by which the soil exerts a suppressive action on different pathogens is through mycoparasitism, which occurs when one fungus is in intimate association with another fungus from which it derives some or all of its nutrients, while conferring no benefit in return. In particular, most published studies on mycoparasitism refer to Trichoderma spp., as these can attack a great variety of phytopathogenic fungi that are responsible for important diseases suffered by crops that are of major economic importance worldwide (Herrera Estrella et al., 1990).

Several studies have reported tight correlations between the natural suppressive capacity of the soil, the level of microbial populations, and the OM content (Erhart et al., 1999; Manici et al., 2004). Agricultural soils characterised by lower OM content, like those of numerous areas of southern Italy (Tarantino et al., 2008), show low microbial populations, with a reduction in the natural soil suppression of phytopathogenic species such as Fusarium oxysporum. Soil management with organic additions can strongly affect the soil microbial population and decrease the incidence of disease caused by soil-borne pathogens.

According to a previous report (Abawi and Widmer, 2000), wastewater used for irrigation can also affect the microbial diversity in the soil, including the relationships among the different species in terms of suppression of plant pathogens such as F. oxysporum, which is responsible for plant vascular diseases. High TSS over the long term and high irrigation volumes of wastewater during the tomato cycle might impact upon the soil mycoflora through temporary enrichment of the soil with readily available carbon sources, which will be rapidly degraded by the soil microorganisms.

\section{Conclusions}

The data from the present study show the effects of irrigation with agro-industrial wastewater on the physical and chemical characteristics and the fungal populations of the soil, and on the tomato crop yield. There were no significant quanti-qualitative differences in the yields between the crops irrigated with the wastewater, with respect to the groundwater. The reuse of wastewater released from agro-industries that are specialised in processing of vegetables are characterised by higher levels of several chemical parameters, including TSS, EC, $\mathrm{COD}, \mathrm{BOD}_{5}, \mathrm{Na}^{+}, \mathrm{K}^{+}$, $\mathrm{Ca}^{2+}, \mathrm{Mg}^{2+}, \mathrm{NH}_{4}-\mathrm{N}, \mathrm{PO}_{4}-\mathrm{P}, \mathrm{OM}$, phenols and chlorides, as compared with groundwater. This induced increases in the parameters related to the soluble salt concentrations in the soil $\left(\mathrm{Na}^{+}, \mathrm{EC}, \mathrm{SAR}\right)$ and in $\mathrm{NH}_{4}-\mathrm{N}$, but showed no significant differences for the chemical parameters of $\mathrm{K}^{+}, \mathrm{Ca}^{2+}, \mathrm{Mg}^{2+}, \mathrm{P}_{2} \mathrm{O}_{5}$ and $\mathrm{OM}$, despite the slightly higher levels of these parameters in the wastewater with respect to the groundwater. However, the reuse of agro-industrial effluents for crop irrigation can also provide easily biodegradable organic compounds (TSS) and readily absorbable 
nutrients $(\mathrm{N}, \mathrm{P})$ to the soil. This stimulates the fungal biodiversity and encourages the development of useful species, to the detriment of plant pathogens, with positive effects on agro-ecosystem stability.

The data from the present study show that secondary treated wastewater irrigation can stimulate fungal populations in the soil, and enrich the antagonists (Tricoderma and Penicillium) of soil-borne pathogens. Indeed, low levels of $F$. oxysporum were observed in the soil irrigated with the wastewater, compared with the groundwater. Considering the intensive cropping techniques and the soil disinfection with chemicals that are usually applied in horticultural areas where crop rotation is not frequently practiced, an alternative technique for the control of plant pests can be very important.

The development of alternative repressive techniques against soil-borne pathogens is an interesting opportunity to promote sustainable agriculture. In this sense, the use of the treated agro-industrial wastewater can contribute greatly to agriculture and to environmental recovery. Increased knowledge of alternative methods for plant protection is necessary, such as this irrigation management with appropriate agro-industrial wastewater.

Based on previous studies and on our data in the present study we suggest that the effects on the soil chemical properties and its interactions with the fungal biocoenoses through long-term irrigation with agroindustrial wastewater should be further investigated.

\section{Acknowledgments}

The authors wish to thank the Italian Ministry for Universities and Research (MIUR) for its financial support under Project In.Te.R.R.A. (contract No 01_01480), co-funded within the Italian Programme "PON/Ricerca e Competitività 2007-2013".

\section{References}

Abawi, G.S, Widmer, T.L. 2000. Impact of soil health management practices on soilborne pathogens, nematodes and root diseases of vegetable crops. Appl. Soil Ecol. 15, 37-47.

Allen, R.G., Pereira, L.S., Raes, D., Smith, M. 1998. Crop Evapotranspiration Guidelines for Computing Crop Water Requirements. Food and Agriculture Organisation of the United Nations (FAO) Irrigation and Drainage Paper, Rome, $\mathrm{n}^{\circ}$ 56.

Allievi, L., Quaroni S. 2002. Gruppi generici di microrganismi. Metodi di analisi microbiologica del suolo, Ministero delle Politiche Agricole e Forestali-Osservatorio Nazionale Pedologico e per la qualità del suolo. Edizione Franco Angeli, Parte II-3, 19-25.

APHA, AWWA, WEF 2005. Standard Methods for the Examination of Water and Wastewater, XXI ed. American Public Health Association, Washington, DC.

Ayers, R.S., Westcot, D.W. 1985. Water quality for agriculture. FAO Irrigation and Drainage Paper $\mathrm{n}^{\circ} 29$, Rome.

Bedbabis, S., Ben Rouina, B., Boukhris, M., Ferrara, G. 2014. Effect of irrigation with treated wastewater on soil chemical properties and infiltration rate. J. Environ. Manag. 133, 45-50.

Chrysargyris, A., Tzortzakis, N. 2015. Municipal solid wastes and mineral fertilizer as an eggplant transplant medium. J. Soil Sci. Plant Nutr. 15, $11-23$.

Decree of the Apulia Region 2005. n² 2036. Direttiva Nitrati: individuazione zone vulnerabili da nitrati. 
Decree of the Ministry for the Environment 2006. $\mathrm{n}^{\circ}$ 152, April 3, Gazzetta Ufficiale n ${ }^{\circ} 88$, Rome April 14, 2006. Italian Guidelines for Wastewater Reuse.

Di Serio, M.G., Lanza, B., Mucciarella, M.R., Russi, F., Iannucci, E., Marfisi, P., Madeo, A. 2008. Effects of olive mill wastewater spreading on the physico-chemical and microbiological characteristics of soil. Int. Biodeter. Biodegrad. 62, 403-407.

Erhart, E., Burian, K., Hart, W, Stich, K. 1999. Suppression of Pythium ultimum by biowaste composts in relation to compost microbial biomass, activity and content of phenolic compounds. J. Phytopathol. 147, 299-305.

Garibaldi, A., Gullino, M.L. 1995. Focus on critical issues in soil and substrate disinfestations towards the year 2000. Acta Horticult. 382, 21-36.

Gatta, G., Libutti, A., Gagliardi, A., Beneduce, L., Brusetti, L., Borruso, L., Disciglio, G., Tarantino, E. 2015. Irrigation with traded agro-industrial wastewater of tomato crop: effects on qualiquantitative characteristics of production and microbiological properties of soil. Agric. Water Manag. 149, 33-43.

Giardini, L. 1992. Agronomia Generale Ambientale e Aziendale. Patron Editore, 1-660.

Gullino, M.L., Garibaldi, A. 1994. Influence of soilless cultivation on soilborne disease. Acta Horticult. 361, 341-354.

Keeney, D.R., Nelson, D.W. 1982. Nitrogen inorganic forms. Methods of soil analysis. Part. $22^{\text {nd }}$ ed. Agr. Monogr. 9 ASA and SSA. Madison, USA, 1982, 643-698.

Lopez, A., Pollice, A., Lonigro, A., Masi, S., Palese, A.M., Cirelli, G.L., Toscano, A., Pasino, R. 2006. Agricultural wastewater reuse in southern Italy. Desalination 187, 323-334.

Manici, L.M., Caputo, F. 2004. Soil suppression of soil-borne pathogens as an agricultural soil fertility parameter. Proc. of the 8th ESA Congress, 421-422.

Manici, L.M., Caputo, F., Bambini, V. 2004. Effect of green manure on Pythium spp. population and microbial communities in intensive cropping systems. Plant Soil. 263, 133-142.

Marsilio, V., Campestre, C., Lanza, B. 2001. Phenolic compounds change during California-style ripe olive processing. Food Chem. 74, 55-60.

Meli, S., Porto, M., Belligno, A., Bufo, S.A., Mazzatura, A., Scopa, A. 2002. Influence of irrigation with lagooned urban wastewater on chemical and microbiological soil parameters in a citrus orchard under Mediterranean condition. Soil Sci. Total Environ. 285, 69-77.

Mojid, M.A., Wyseure G.C.L., Biswas, S.K., 2012. Requirement of nitrogen, phosphorus and potassium fertilizer for wheat cultivation under irrigation by municipal wastewater. J. Soil Sci. Plant Nutr. 12, 655-665.

Olsen, S.R., Cole, C.V., Watanabe, F.S., Dean, L.A. 1954. Estimation of available phosphorus in soil by extraction with sodium bicarbonate. USDA Circular, Washington, DC. 939, 1-19.

Papavizas, G. 1967. Evolution of various and antimicrobial agents for isolation of Fusarium from soil. Phytopathology. 57, 848-852.

Rubino, P., Lonigro, A. 2008. Municipal treated wastewater irrigation. Microbiological risk evaluation. Ital. J. Agron. 2, 119-124.

Saadi, H., Laor, Y., Raviv, M., Medina, S. 2007. Land spreading of olive mill wastewater. Effects on soil microbial activity and potential phytotoxicity. Chemosphere. 66, 75-83.

Tarantino, E., Frabboni, L., Giuliani, M.M., Gatta, G., Disciglio, G., Libutti, A., Basso, G., de 
Simone, G. 2008. Opuscolo divulgativo Lotta alla desertificazione, 1-81.

Tardioli, S., Bannè, E.T.G., Santori, F. 1997. Speciesspecific selection on soil fungal population after olive mill wastewater treatment. Chemosphere 34, 2329-2336.

Vivaldi, G.A., Camposeo, S., Rubino, P., Lonigro, A. 2013. Microbial impact of different types of municipal wastewaters used to irrigate nectarines in southern Italy. Agricult. Ecosys. Environ. 181, $50-57$.

Walkley, A., Black, I.A. 1934. An examination of the Degtjareff method for determining organic carbon in soils: effect of variations in digestion conditions and of inorganic soil constituents. Soil Sci. 63, 251-263. 